\title{
Repurposing cimetidine for cholangiocarcinoma: Antitumor effects in vitro and in vivo
}

\author{
PAWEENA DANA ${ }^{1-3}$, KULTHIDA VAETEEWOOTTACHARN ${ }^{1-3}$, RYUSHO KARIYA $^{3}$, \\ KOUKI MATSUDA $^{3}$, SOPIT WONGKHAM ${ }^{1,2}$ and SEIJI OKADA ${ }^{3}$ \\ ${ }^{1}$ Department of Biochemistry and ${ }^{2}$ Liver Fluke and Cholangiocarcinoma Research Center, Faculty of Medicine, \\ Khon Kaen University, Khon Kaen 40002, Thailand; ${ }^{3}$ Division of Hematopoiesis, \\ Center for AIDS Research, Kumamoto University, Kumamoto 860-0811, Japan
}

Received September 12, 2015; Accepted September 27, 2016

DOI: $10.3892 / \mathrm{ol} .2017 .5563$

\begin{abstract}
Cimetidine is a histamine type-2 $\left(\mathrm{H}_{2}\right)$ receptor antagonist that has been demonstrated to have antitumor effects on various types of malignancy. However, its effect on cholangiocarcinoma (CCA), a chemotherapy-resistant bile duct tumor, has yet to be investigated. In the present study, the antitumor activity of cimetidine in vitro and in vivo was evaluated. A methylthiotetrazole assay revealed that the proliferation of certain CCA cell lines was inhibited by cimetidine, which induced the caspase-dependent apoptosis of CCA cells via suppression of the protein kinase B signaling pathway. Suppression of Akt phosphorylation, caspase-3, -8 and -9 activation, phosphotidylserine exposure determined by Annexin V binding assay and the presence of a sub-G1 population were demonstrated by western blotting and flow cytometry analysis. In a CCA xenograft mouse model cimetidine inhibited the growth of CCA cells without observable adverse effects. These results suggest that cimetidine has the potential to be an effective antitumor agent for the treatment of CCA.
\end{abstract}

\section{Introduction}

Cholangiocarcinoma (CCA) is a highly lethal type of cancer that arises from the bile duct epithelium (1). Although CCA

Correspondence to: Professor Seiji Okada, Division of Hematopoiesis, Center for AIDS Research, Kumamoto University, 2-2-1 Honjo, Chuou-ku, Kumamoto 860-0811, Japan

E-mail: okadas@kumamoto-u.ac.jp

Dr Kulthida Vaeteewoottacharn, Department of Biochemistry, Faculty of Medicine, Khon Kaen University, 123 Moo 16 Mittapap Road, Khon Kaen 40002, Thailand

E-mail: kulthidava@kku.ac.th

Abbreviations: CCA, cholangiocarcinoma; FACS, fluorescenceactivated cell sorting; PI, propidium iodide

Key words: cimetidine, cholangiocarcinoma, apoptosis, protein kinase B, xenograft model is a rare form of cancer, the global incidence of CCA is increasing, particularly that of the intrahepatic subtype (2). However, the highest incidence of CCA has been reported in the northeast of Thailand where the carcinogenic liver fluke Opisthorchis viverrini is considered a causative agent (3). The early diagnosis of CCA is challenging as patients with CCA typically have non-specific symptoms, and CCA tumor markers are yet to be developed (4). The majority of patients with CCA present with a late-stage disease that is frequently inoperable, and the outcomes of conventional chemotherapy or radiotherapy are unsatisfactory (5). Therefore, a unique approach to developing novel targeting therapies is required to reduce CCA-associated mortality.

Cimetidine is an antagonist of histamine type- $2\left(\mathrm{H}_{2}\right)$ receptors and is indicated for patients with gastro-esophageal reflux diseases, peptic ulcers or hypersecretory conditions $(6,7)$. The effect of cimetidine on the survival of patients has been reported in various types of cancer, including gastric cancer (8), colorectal cancer $(6,9,10)$, renal cell carcinoma (11), malignant melanoma (12) and glioblastoma (13). Numerous molecular mechanisms underlying the anticancer activities of cimetidine have been revealed, including the inhibition of cell proliferation by blocking the cell growth-promoting effect of histamine (14), the inhibition of tumor angiogenesis (15), the stimulation host immune responses (16) and the suppression of cell adhesion (17). However, the effects of cimetidine in CCA have yet to be demonstrated.

In the present study, the anti-CCA activity of cimetidine was examined and the antiproliferative and apoptosis-inducing effects of cimetidine were determined. This was revealed to be partially due to the suppression of protein kinase B (Akt) phosphorylation. A CCA transplant xenograft Balb/c recombination activating gene 2 ( Rag-2)/Janus kinase 3 (Jak3) double deficient $(\mathrm{Balb} / \mathrm{c} \mathrm{R} / \mathrm{J})$ mouse model demonstrated the anti-CCA effects of cimetidine in vivo. The results of the current study suggest that cimetidine is a potential anti-CCA agent.

\section{Materials and methods}

Cell lines and reagents. The KKU-M055, KKU-M213 and KKU-214 distinct human CCA cell lines (18) were provided by Dr. Banchop Spira (Khon Kaen University, Khon Kaen, 
Thailand). The cell lines were maintained in Dulbecco's modified Eagle's medium (DMEM; Wako Pure Chemical Industries, Ltd., Osaka, Japan) supplemented with $10 \%$ fetal bovine serum (HyClone Laboratories, Inc., Logan, UT, USA), $100 \mathrm{U} / \mathrm{ml}$ penicillin and $100 \mu \mathrm{g} / \mathrm{ml}$ streptomycin in a humidified incubator at $37^{\circ} \mathrm{C}$ and $5 \% \mathrm{CO}_{2}$. Cimetidine was purchased from Sigma-Aldrich (Merck Millipore, Darmstadt, Germany).

MTT tetrazolium dye assay. The antiproliferative activities of cimetidine in CCA cell lines were evaluated using an MTT assay (Sigma-Aldrich; Merck Millipore). Briefly, 5x10 3 cells were seeded in $100 \mu \mathrm{l}$ of DMEM onto 96-well plates in triplicate and incubated overnight at $37^{\circ} \mathrm{C}$ in an atmosphere of $5 \% \mathrm{CO}_{2}$. The medium was then replaced with fresh DMEM containing various concentrations of cimetidine $(0,2,4,6,8$ or $10 \mathrm{mM}$ ) and incubated at $37^{\circ} \mathrm{C}$ for 24 or $48 \mathrm{~h}$. MTT solution $(0.5 \mathrm{mg} / \mathrm{ml}$ final concentration) was subsequently added to each well. Following a 3 -h incubation, $100 \mu \mathrm{l}$ acidified isopropanol ( $\mathrm{HCl} 34 \mu \mathrm{l} / 10 \mathrm{ml}$ isopropanol) was added to dissolve the formazan crystals. The absorption values at $595 \mathrm{~nm}$ were determined using an automatic microplate reader (Ascent Software Version 2.6; Multiskan; Thermo Fisher Scientific, Inc., Waltham, MA, USA). The values were normalized to the control (untreated) samples.

Annexin $V$ binding assay. The number of apoptotic cells was quantified using an Annexin V-fluorescein isothiocyanate (FITC) apoptosis detection kit (eBioscience, Inc., San Diego, CA, USA). Following treatment with cimetidine, the dead or unadhered cells were collected and adherent cells were harvested by trypsinization (trypsin-EDTA solution; Sigma-Aldrich; Merck Millipore), washed with Annexin V binding buffer and incubated with Annexin V-FITC at room temperature for $15 \mathrm{~min}$ in the dark. Next, stained cells were treated with $1 \mu \mathrm{g} / \mathrm{ml}$ propidium iodide (PI; Sigma-Aldrich) prior to flow cytometry analysis. The cells were analyzed using a BD LSR II ${ }^{\mathrm{TM}}$ flow cytometer (BD Biosciences, Franklin Lakes, NJ, USA). Data analysis was performed using FlowJo ${ }^{\mathrm{TM}}$ software (version 9.9.3; Tree Star, Inc., Ashland, OR, USA).

PI staining. CCA cells were seeded at a density of $2 \times 10^{5}$ cells/well into a six-well plate and incubated overnight at $37^{\circ} \mathrm{C}$ in an atmosphere of $5 \% \mathrm{CO}_{2}$ followed by treatment with cimetidine $(0,5$ and $10 \mathrm{mM})$ for 24 and $48 \mathrm{~h}$. The unadhered cells were collected and adherent cells were harvested by trypsinization, washed twice with cold phosphate-buffered saline and fixed in $70 \%$ ethanol at $4^{\circ} \mathrm{C}$ overnight. The fixed cells were stained with $10 \mu \mathrm{g} / \mathrm{ml}$ PI and incubated at room temperature for $30 \mathrm{~min}$ in the dark. The sub- $\mathrm{G}_{1}$ fraction of each cell sample was analyzed using a BD LSR II ${ }^{\mathrm{TM}}$ flow cytometer. Data analysis was performed using Flow $\mathrm{Jo}^{\mathrm{TM}}$ software.

Protein extraction and western blot analysis. Cells were lysed in NP-40 lysis buffer (Dojindo Molecular Technologies, Inc., Kumamoto, Japan), containing $50 \mathrm{mM}$ Tris- $\mathrm{HCl}$ (pH 7.4), $150 \mathrm{mM} \mathrm{NaCl}, 1 \%$ NP-40, $1 \mathrm{mM} \mathrm{NaF}, 1 \mathrm{mM}$ $\mathrm{Na}_{3} \mathrm{VO}_{4}$ (Sigma-Aldrich; Merck Millipore) and a protease inhibitor cocktail (Nacalai Tesque, Inc., Kyoto, Japan), and the supernatant was collected. Protein concentrations were evaluated using a bicinchoninic acid protein assay (Thermo
Fisher Scientific, Inc.). The proteins extracted from the cell lysates $(20 \mu \mathrm{g})$ were separated using $10 \%$ sodium dodecyl sulfate polyacrylamide gel electrophoresis and transferred onto polyvinylidene fluoride membranes (GE Healthcare Life Sciences, Chalfont, UK). The membrane was blocked with 5\% skim milk in Tris-buffered saline with $0.1 \%$ Tween 20 (TBST) for $1 \mathrm{~h}$ at room temperature. Next, the membrane was probed with $\beta$-actin-C-2 (catalog no., sc-8432; Santa Cruz Biotechnology, Inc., Dallas, TX, USA), cleaved caspase-3 (Asp175; 5A1E; catalog no., 9664; Cell Signaling Technology, Inc., Danvers, MA, USA), cleaved caspase-8 (Asp931; 18C8; catalog no., 9496; Cell Signaling Technology, Inc.), caspase-9 (Cell Signaling Technology, Inc.), protein kinase B (Akt) (human specific, catalog no., 9502; Cell Signaling Technology, Inc.) and phospho-Akt (Thr308; D25E6; catalog no., 13038; Cell Signaling Technology, Inc.) primary antibodies (dilution, $1: 1,000)$ overnight at $4^{\circ} \mathrm{C}$. After washing three times with TBST, the membrane was incubated with horseradish peroxidase (HRP)-conjugated anti-rabbit (catalog no., 7074; Cell Signaling Technology, Inc.) and anti-mouse (catalog no., 7076; Cell Signaling Technology, Inc.) immunoglobulin $\mathrm{G}$ secondary antibodies (dilution, 1:2,000) for $2 \mathrm{~h}$ at room temperature. Detection of the proteins was performed using Chemi-Lumi One Super reagents (Nacalai Tesque, Inc.). The protein bands were visualized using the ImageQuant LAS400 system (GE Healthcare Life Sciences).

Xenograft mouse model. Balb/c RJ mice were established as described previously (19) and were bred, housed and monitored in the animal research facility at Kumamoto University (Kumamoto, Japan) according to the institutional guidelines. In the specific pathogen free conditions, mice were kept at $22 \pm 2{ }^{\circ} \mathrm{C}$ in $40-80 \%$ humidity, with a 12 -h light/dark cycle. Food and UV-treated water were supplied ad libitum. The Institutional Animal Care and Use Committee of Kumamoto University approved all experimental procedures and protocols used in the current study. KKU-M213 cells $\left(2 \times 10^{6}\right)$ were subcutaneously injected into the flanks of the 6-8 week-old female Balb/c RJ mice. The mice were administered an intraperitoneal injection of $100 \mu \mathrm{l}$ dimethyl sulfoxide (DMSO) or cimetidine $(200 \mathrm{mg} / \mathrm{kg})$ one day following cell transplantation, and then every day for a total of 12 days. Tumor growth was monitored every 3 days using a vernier caliper. On day 13, mice were sacrificed by cervical dislocation and tumors were removed and weighed. Body weights were recorded twice a week in order to observe the condition of the mice.

Statistical analysis. The data are expressed as the mean \pm standard deviation. The significance of differences observed between the experimental groups was determined using the Student's $t$-test. $\mathrm{P}<0.05$ was considered to indicate a statistically significant result. All of the statistical analyses were performed using SPSS 17.0 (SPSS, Inc., Chicago, IL, USA).

\section{Results}

Antiproliferative effects of cimetidine on CCA cells. An MTT assay was used to determine whether treatment with cimetidine induced the inhibition of CCA cell proliferation. KKU-M055, KKU-M213 and KKU-M214 CCA cells were 

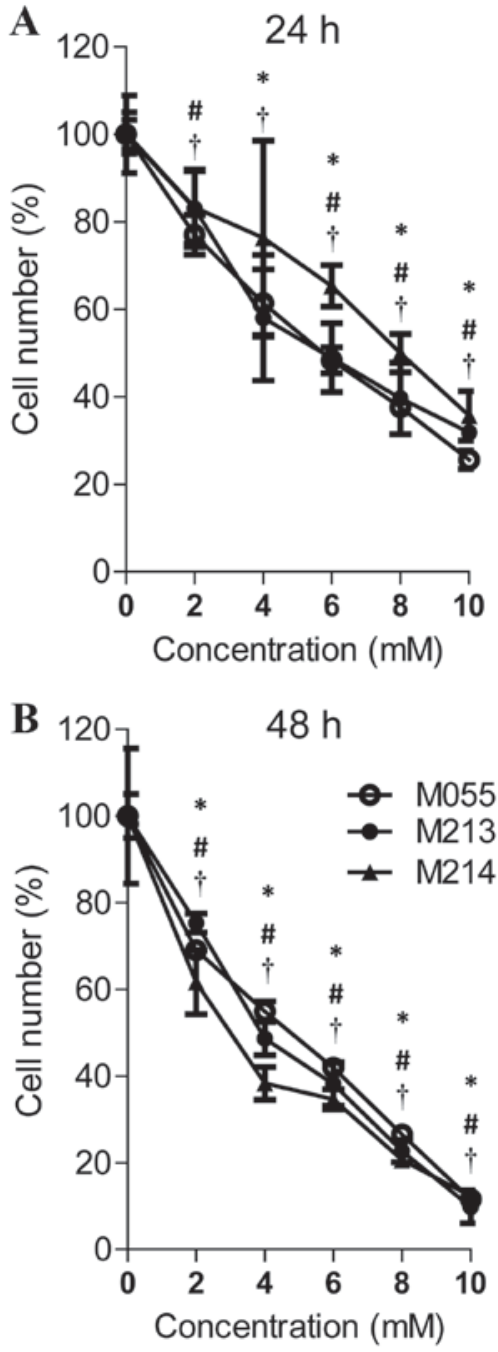

Figure 1. Effects of cimetidine on the proliferation of the KKU-M055, KKU-M213 and KKU-M214 CCA cell lines. CCA cells were treated with $0,2,4,6,8$ and $10 \mathrm{mM}$ cimetidine for (A) $24 \mathrm{~h}$ and (B) $48 \mathrm{~h}$. The results demonstrated that cimetidine inhibited CCA cell proliferation in a dose- and time-dependent manner. The data are expressed as the mean \pm standard deviation of three independent experiments. CCA, cholangiocarcinoma. ${ }^{*} \mathrm{P}<0.05$ in KKU-M055. ${ }^{*} \mathrm{P}<0.05$ in KKU-M213. ${ }^{\mathrm{P}} \mathrm{P}<0.05$ in KKU-M214. The statistical differences for each time point were reported vs. untreated cells.

treated with cimetidine at various concentrations for 24 or $48 \mathrm{~h}$ before the MTT assay was performed. As shown in Fig. 1, cimetidine effectively inhibited cell proliferation in a doseand time-dependent manner. Treatment with 2, 4, 6, 8 and $10 \mathrm{mM}$ cimetidine for $24 \mathrm{~h}$ and treatment with $2,4,6,8$ and $10 \mathrm{mM}$ cimetidine for $48 \mathrm{~h}$ significantly inhibited cell growth in KKU-M055 cells $(\mathrm{P}<0.05)$. The growth suppression effect on KKU-M213 cells was observed in 4, 6, 8, $10 \mathrm{mM}$ cimetidine treatment at $24 \mathrm{~h}$ and in 2, 4, 6, 8, $10 \mathrm{mM}$ cimetidine treatment at $48 \mathrm{~h}$. Cimetidine effectively inhibited KKU-M214 at 2, 6, $8,10 \mathrm{mM}$ concentration at $24 \mathrm{~h}$ and at 2, 4, 6, 8, $10 \mathrm{mM}$ at $48 \mathrm{~h}$. The half-maximal inhibitory concentration $\left(\mathrm{IC}_{50}\right)$ values of cimetidine for KKU-M055, KKU-M213 and KKU-M214 cells were 5.44, 5.69 and $7.83 \mathrm{mM}$ at $24 \mathrm{~h}$, and 4.07, 3.95 and $3.18 \mathrm{mM}$ at $48 \mathrm{~h}$, respectively.

Cimetidine induces apoptosis in CCA cells. In subsequent experiments, it was determined whether the observed
A

$24 \mathrm{~h}$

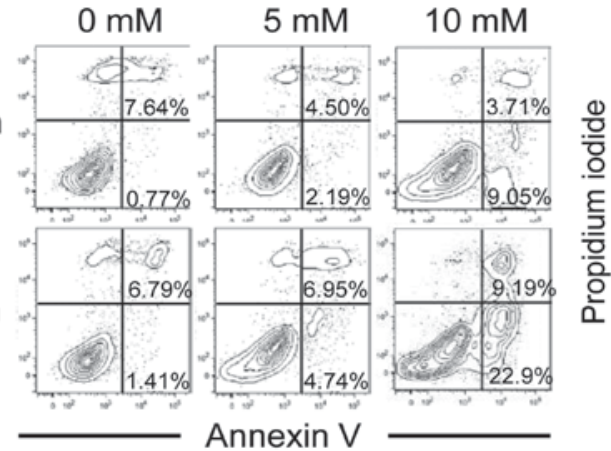

B

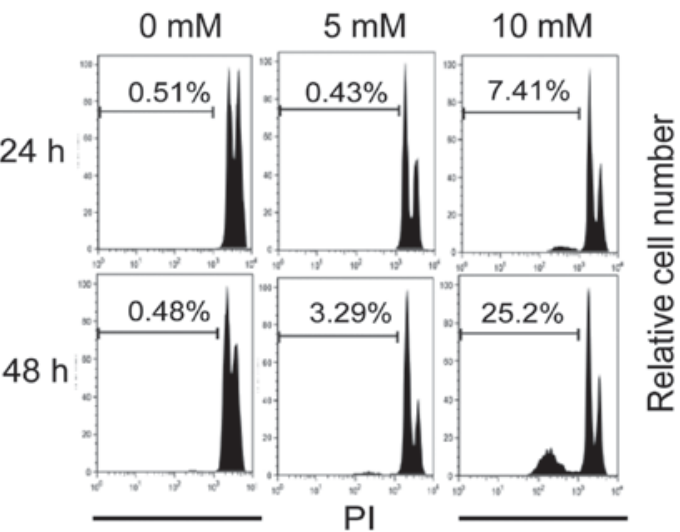

C

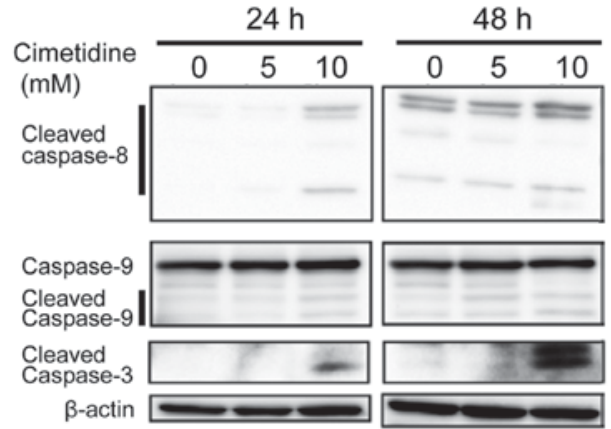

Figure 2. Effects of cimetidine on the induction of apoptosis in CCA cells KKU-M213 cells were treated with cimetidine at concentrations of 0,5 and $10 \mathrm{mM}$ for 24 and $48 \mathrm{~h}$. (A) Apoptotic cell death. At the indicated times, the cells were harvested, stained with Annexin V-FITC and $1 \mu \mathrm{g} / \mathrm{ml}$ propidium iodide and analyzed using flow cytometry. Right upper quadrant represents Annexin V-PI double positive cells (late apoptotic cells) and the right lower quadrant represents Annexin $V$ positive cells (early apoptotic cells). Following treatment with 0,5 and $10 \mathrm{mM}$ cimetidine, the number of Annexin $\mathrm{V}$ positive cells was increased in dose- and time-dependent manners. (B) Sub- $\mathrm{G}_{1}$ population. Cells were fixed in $70 \%$ ethanol, stained with $10 \mu \mathrm{g} / \mathrm{ml}$ propidium iodide and the sub- $\mathrm{G}_{1}$ population was determined by flow cytometry. Percentages of the sub-G1 population were indicated in the graphs, which revealed that the sub-G1 populations were increased in a time-dependent manner following treatment with cimetidine. (C) Caspase-dependent apoptosis. Total proteins were extracted and western blotting was performed. Cimetidine treatment induced the expression of cleaved caspase- $8,-9$ and -3 in a time-dependent manner. The data are representative of three independent experiments. CCA, cholangiocarcinoma; FITC, fluorescein isothiocyanate.

suppressive effects of cimetidine in the MTT assay were due to the induction of apoptosis. An Annexin V binding assay was used to detect the apoptotic cells. As presented in Fig. 2A, the proportions of early-stage (Annexin V-positive/PI-negative) and late-stage (Annexin V-positive/PI-positive) apoptotic cells increased in a dose- and time-dependent manner. The sub- $\mathrm{G}_{1}$ 


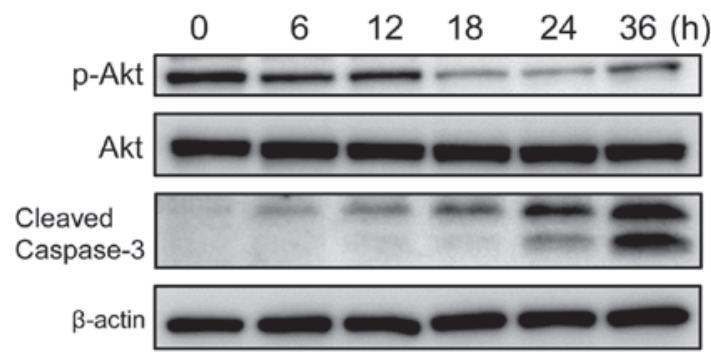

Figure 3. Effects of cimetidine on Akt and p-Akt protein expression in KKU-M213 CCA cells treated with $10 \mathrm{mM}$ cimetidine for $6,12,18,24$ and $36 \mathrm{~h}$ were analyzed by western blotting. $\beta$-actin served as the loading control. Cimetidine inhibited Akt phosphorylation and caspases-3 activation in a time-dependent manner. The data are representative of two independent experiments. CCA, cholangiocarcinoma; Akt, protein kinase B; p-Akt, phosphorylated Akt.

population was also analyzed using flow cytometry. As shown in Fig. 2B, the sub- $\mathrm{G}_{1}$ population (apoptotic fraction) increased in a dose- and time-dependent manner. These results suggest that the cell growth inhibition induced by cimetidine treatment occurs via the stimulation of apoptosis. To investigate caspase dependency in cimetidine-dependent apoptosis, a western blot analysis was performed in order to detect the activation of caspases. Cleaved caspase-3, cleaved caspase-9 and cleaved caspase- 8 expression levels were determined to be dose- and time-dependently higher in the cells treated with cimetidine, compared with untreated cells (Fig. 2C). These results suggest that cimetidine induces apoptosis in CCA cells via caspase-dependent intrinsic and extrinsic signaling pathways.

Cimetidine suppresses the phosphorylation of Akt signaling. To explore the molecular mechanisms underlying cimetidine-induced apoptosis in the KKU-M213 CCA cell line, and to determine whether the Akt signaling pathway was involved in this effect, KKU-M213 cells were treated with $10 \mathrm{mM}$ cimetidine at various time points $(0-36 \mathrm{~h})$. The results of the western blot analysis are presented in Fig. 3. Cimetidine significantly suppressed the phosphorylation of Akt in a time-dependent manner, but did not affect total Akt expression levels. This result suggested that cimetidine induces apoptosis in KKU-M213 cells by inactivating the Akt signaling pathway.

In vivo effects of cimetidine in severely immunodeficient mice. The results of the in vitro experiments suggested that cimetidine may be an effective treatment for CCA; therefore, the in vivo effects of cimetidine in an immunodeficient mouse model were investigated. Severely immunodeficient Balb/c R/J mice were subcutaneously injected with $2 \times 10^{6} \mathrm{KKU}-\mathrm{M} 213$ cells in the flank. A dose of $200 \mathrm{mg} / \mathrm{kg}$ cimetidine or DMSO alone was administered via an intraperitoneal injection on day 1 following cell inoculation, and then every day for 12 days. As shown in Fig. 4A, the weights of the tumors in cimetidine-treated mice were significantly lower $(0.108 \pm 0.05 \mathrm{~g}$; $\mathrm{n}=22)$, compared with those in untreated mice $(0.165 \pm 0.07 \mathrm{~g}$; $\mathrm{n}=26 ; \mathrm{P}=0.0024)$. All mice were observed to be healthy and no significant differences were identified in body weights between the treated and control groups (Fig. 4B).
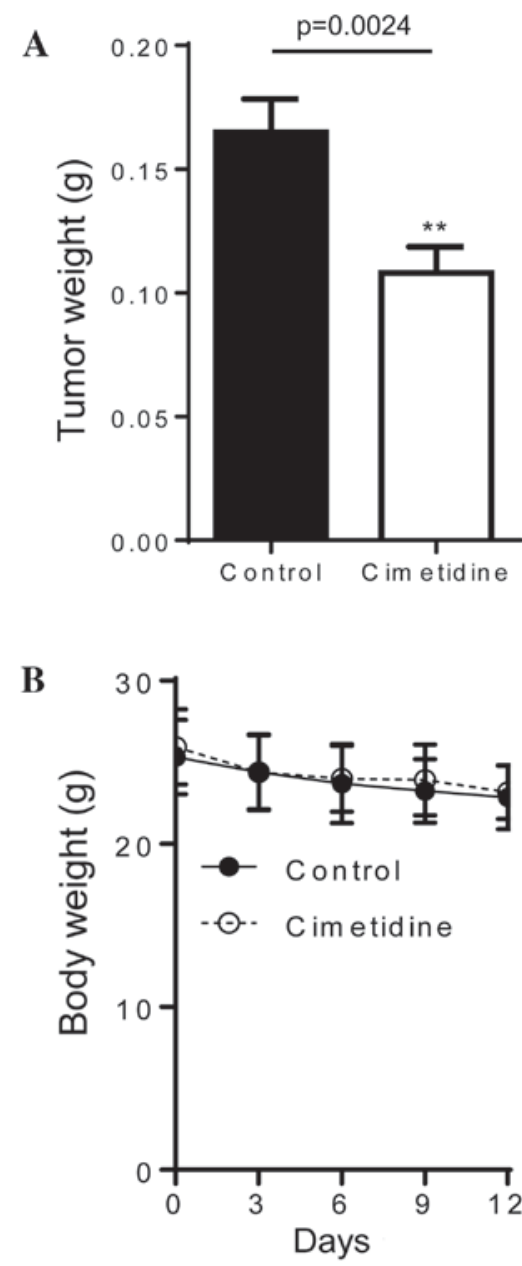

Figure 4. Inhibitory effects of cimetidine on the growth of CCA cells in vivo. (A) KKU-M213 cells were subcutaneously injected into Balb/c $\mathrm{R} / \mathrm{J}$ mice and the subsequent tumors were isolated for weighing on day 13 following cell transplantation. (B) The body weights of the mice from the control and cimetidine-treated groups were determined every three days. The results indicated that cimetidine significantly inhibited tumor growth when compared with the control. The data are presented as the mean \pm standard deviation of three independent experiments. ${ }^{* *} \mathrm{P}<0.01$ vs. control. Balb/c RJ mice, Balb/c Rag-2/Jak3-double deficient mice; CCA, cholangiocarcinoma.

\section{Discussion}

In the present study, the $\mathrm{H}_{2}$ receptor antagonist cimetidine was demonstrated to be a potentially effective chemotherapeutic agent for CCA. Cimetidine induced caspase-dependent apoptotic cell death in CCA cells through the inhibition of Akt phosphorylation. Furthermore, cimetidine inhibited tumor growth in human CCA-bearing mice with no observable adverse effects. As cimetidine is frequently used as $\mathrm{H}_{2}$ receptor antagonist without serious adverse effects $(20,21)$, it will be useful to repurpose cimetidine for the treatment of CCA.

CCA is the second most common type of liver cancer and exhibits aggressive characteristics, including a general resistance to conventional chemotherapy (5). The molecular signature of CCA has previously been investigated, which revealed that increased expression of inflammation-related proteins was often observed in CCA (22). Numerous signaling pathways are involved in the carcinogenesis of CCA, including transforming growth factor- $\beta /$ mothers against 
decapentaplegic homolog, interleukin-6/signal transducer and activator of transcription, phosphoinositide 3-kinase/Akt, Wnt, rapidly accelerated fibrosarcoma/mitogen-activated protein kinase kinase/mitogen-activated protein kinase and Notch (23). Activated Akt and phospho-Akt are recognized transcription activation and anti-apoptotic signaling pathway components (24). Akt signaling is a critical pathway in CCA and its potential use as a target for CCA treatment has previously been suggested (25). In the current study, it was demonstrated that the phosphorylation of Akt was suppressed by cimetidine, and corresponded to the induction of apoptosis in CCA. Therefore, it was hypothesized that cimetidine induces apoptosis in CCA cell lines via the inhibition of Akt phosphorylation (25).

Cimetidine is considered to improve the survival of patients with malignant tumors such as gastric and colorectal cancers $(6,8,9)$. It has been demonstrated to inhibit tumor growth by several underlying mechanisms, including the inhibition of cancer cell proliferation (20), the blockade of tumor angiogenesis (15) and the enhancement of immune activity (26). A previous study demonstrated that cimetidine induced myeloid-derived suppressor cell apoptosis in mice (27). These results suggested that cimetidine directly suppresses tumor growth via various antitumor effects and indirectly via specific modifications of the tumor microenvironment, including angiogenesis, and of the host immune responses. Therefore, combination treatment with cimetidine may potentiate the effects of current chemotherapy regimens (5-fluorouracil or gemcitabine with oxaliplatin) that are employed to treat patients with CCA.

In conclusion, the present study demonstrated the potent anti-CCA activity of cimetidine in vitro and in vivo. To the best of our knowledge, this study is the first to demonstrate that cimetidine induces caspase-dependent apoptosis via the suppression of the Akt signaling pathway. These results suggest that cimetidine is a potentially effective candidate for the treatment of patients with CCA.

\section{Acknowledgements}

The authors would like to thank Ms. I. Suzu and Ms. S. Fujikawa (Division of Hematopoiesis, Center for AIDS Research, Kumamoto University, Kumamoto, Japan) for their technical assistance and Ms. Y. Kanagawa (Division of Hematopoiesis, Center for AIDS Research, Kumamoto University, Kumamoto, Japan) for secretarial assistance. This study was supported in part by Grants-in-Aid for Scientific Research (grant no. 25114711) from the Ministry of Education, Science, Sports and Culture of Japan, and by the Royal Golden Jubilee-PhD Program co-funding with Khon Kaen University, Thailand (to Ms. Paweena Dana and Dr. Sopit Wongkham; no. PHD/0192/2552).

\section{References}

1. Vatanasapt V, Sriamporn S and Vatanasapt P: Cancer control in Thailand. Jpn J Clin Oncol 32: (Suppl) S82-S91, 2002.

2. Endo I, Gonen M, Yopp AC, Dalal KM, Zhou Q, Klimstra D, D'Angelica M, DeMatteo RP, Fong Y, Schwartz L, et al: Intrahepatic cholangiocarcinoma: Rising frequency, improved survival, and determinants of outcome after resection. Ann Surg 248: 84-96, 2008.
3. Sripa B and Pairojkul C: Cholangiocarcinoma: Lessons from Thailand. Curr Opin Gastroenterol 24: 349-356, 2008.

4. Wongkham S and Silsirivanit A: State of serum markers for detection of cholangiocarcinoma. Asian Pac J Cancer Prev 13: (Suppl) S17-S27, 2012.

5. Anderson CD, Pinson CW, Berlin J and Chari RS: Diagnosis and treatment of cholangiocarcinoma. Oncologist 9: 43-57, 2004.

6. Adams WJ and Morris DL: Short-course cimetidine and survival with colorectal cancer. Lancet 344: 1768-1769, 1994.

7. Freston JW: Cimetidine: II. Adverse reactions and patterns of use. Ann Intern Med 97: 728-734, 1982.

8. Tønnesen H, Knigge U, Bülow S, Damm P, Fischerman K, Hesselfeldt P, Hjortrup A, Pedersen IK, Pedersen VM and Siemssen OJ: Effect of cimetidine on survival after gastric cancer. Lancet 2: 990-992, 1988.

9. Adams W and Morris D: Cimetidine and colorectal cancer. Dis Colon Rectum 39: 111-112, 1996.

10. Kelly MD, King J, Cherian M, Dwerryhouse SJ, Finlay IG, Adams WJ, King DW, Lubowski DZ and Morris DL: Randomized trial of preoperative cimetidine in patients with colorectal carcinoma with quantitative assessment of tumor-associated lymphocytes. Cancer 85: 1658-1663, 1999.

11. Dexeus FH, Logothetis CJ, Sella A, Fitz K, Amato R, Reuben JM and Dozier N: Phase II study of coumarin and cimetidine in patients with metastatic renal cell carcinoma. J Clin Oncol 8: 325-329, 1990.

12. Morton RF, Creagan ET, Cullinan SA, Mailliard JA, Ebbert L, Veeder MH and Chang M: Phase II studies of single-agent cimetidine and the combination N-phosphonacetyl-L-aspartate (NSC-224131) plus L-alanosine (NSC-153353) in advanced malignant melanoma. J Clin Oncol 5: 1078-1082, 1987.

13. Lefranc F, Yeaton P, Brotchi J and Kiss R: Cimetidine, an unexpected anti-tumor agent, and its potential for the treatment of glioblastoma (review). Int J Oncol 28: 1021-1030, 2006.

14. Adams WJ, Lawson JA and Morris DL: Cimetidine inhibits in vivo growth of human colon cancer and reverses histamine stimulated in vitro and in vivo growth. Gut 35: 1632-1636, 1994.

15. Natori T, Sata M, Nagai R and Makuuchi M: Cimetidine inhibits angiogenesis and suppresses tumor growth. Biomed Pharmacother 59: 56-60, 2005.

16. Sahasrabudhe DM, McCune CS, O'Donnell RW and Henshaw EC: Inhibition of suppressor T lymphocytes (Ts) by cimetidine. J Immunol 138: 2760-2763, 1987.

17. Kobayashi K, Matsumoto S, Morishima T, Kawabe T and Okamoto T: Cimetidine inhibits cancer cell adhesion to endothelial cells and prevents metastasis by blocking E-selectin expression. Cancer Res 60: 3978-3984, 2000.

18. Seubwai W, Vaeteewoottacharn K, Hiyoshi M, Suzu S, Puapairoj A, Wongkham C, Okada S and Wongkham S: Cepharanthine exerts antitumor activity on cholangiocarcinoma by inhibiting NF-kappaB. Cancer Sci 101: 1590-1595, 2010.

19. Ono A, Hattori S, Kariya R, Iwanaga S, Taura M, Harada H, Suzu S and Okada S: Comparative study of human hematopoietic cell engraftment into BALB/c and C57BL/6 strain of rag-2/jak3 double-deficient mice. J Biomed Biotechnol 2011: 539748, 2011.

20. Kubecova M, Kolostova K, Pinterova D, Kacprzak G and Bobek V: Cimetidine: An anticancer drug? Eur J Pharm Sci 42: 439-444, 2011.

21. Morris DL and Adams WJ: Cimetidine and colorectal cancer-old drug, new use? Nat Med 1: 1243-1244, 1995.

22. Vaeteewoottacharn K, Seubwai W, Bhudhisawasdi V, Okada S and Wongkham S: Potential targeted therapy for liver fluke associated cholangiocarcinoma. J Hepatobiliary Pancreat Sci 21: 362-370, 2014.

23. Maemura K, Natsugoe S and Takao S: Molecular mechanism of cholangiocarcinoma carcinogenesis. J Hepatobiliary Pancreat Sci 21: 754-760, 2014.

24. Datta SR, Brunet A and Greenberg ME: Cellular survival: A play in three Akts. Genes Dev 13: 2905-2927, 1999.

25. Schmitz KJ, Lang H, Wohlschlaeger J, Sotiropoulos GC, Reis H, Schmid KW and Baba HA: AKT and ERK1/2 signaling in intrahepatic cholangiocarcinoma. World J Gastroenterol 13: 6470-6477, 2007.

26. Adams WJ, Morris DL, Ross WB, Lubowski DZ, King DW and Peters L: Cimetidine preserves non-specific immune function after colonic resection for cancer. Aust N Z J Surg 64: 847-852, 1994.

27. Zheng Y, Xu M, Li X, Jia J, Fan K and Lai G: Cimetidine suppresses lung tumor growth in mice through proapoptosis of myeloid-derived suppressor cells. Mol Immunol 54: 74-83, 2013. 